\title{
Valuable Subversions: Gendered Generativity and Sorcerous Production in Central Mozambique
}

\author{
Bjørn Enge Bertelsen
}

\begin{abstract}
How is one to analyze the existence of a subterranean dwarfish couple (zwidoma) occupying the space underneath cooking places and whose central purpose is to reinforce a market woman's sales-but simultaneously feeding off her very body? Using urban and rural ethnographic material from central Mozambique, where such assemblages comprising the zwidoma and a woman are integral to economic life and social orders, this article contextualizes such constellations-effectively interferences within various domains of value-by undertaking an analysis of gendered modalities of generativity. Further, by meditating on various understandings of cosmology and, ultimately, the dynamics constituting the realms of the real, it presents an alternative to influential analyses of capitalism, such as the notion of "occult economies." An argument is made not only for value's dynamic and changeable nature but also for the necessity to appreciate instances of its subversion with destructive effects. The article underlines, therefore, how such subversions of value, in various forms, is in line with Tsing's (2015) general argument that critical explorations of capitalism and regimes of valuation and production are best undertaken in peri-capitalist zones—such as urban and rural Mozambique.
\end{abstract}

Key words: value; gender; sorcery; economy; generativity; Mozambique

\section{Introduction: Food, Women and an Extensive Household}

Between 1998 and January 2016 I undertook multiple periods of fieldwork in and around the central Mozambican towns of Chimoio and, more recently, Gondola. In my work I have continuously shifted

Bjørn Enge Bertelsen, University of Bergen, Department of Social Anthropology, bjorn.bertelsen@uib.no

(C) 2016 Authors

LiU Electronic Press, DOI 10.3384/VS.2001-5992.164141

http://valuationstudies.liu.se 
between stays in a rural locale that I call "Honde," as well the urban and peri-urban areas of Chimoio and Gondola. Rather than being a deliberate fieldwork strategy on my part, this long-term oscillation between sites has instead reflecte42d my interlocutors' relocations corresponding to changing seasonal and occupational aspects of their households. Moreover, such movements are also, at times, occasioned by recurring security concerns, in particular waves of robberies, instances of police and state violence and, more recently, the waxing and waning of prospects of civil unrest due to a deteriorating political situation in Mozambique from 2012 onward (see, e.g., Bertelsen 2009a, 2016).

Recurring movements between rural and peri-urban contexts aside, almost all economic activity is nevertheless based on or related to agricultural production: Here, the tilling of the soil crucially produces maize from which is made sadza-the staple dish that comprises the lunch and evening meal for a majority of the predominantly poor population. Normally consisting of maize meal (or, more rarely, meal from sorghum or cassava), the sadza is cooked into a porridge and served with relish, normally a sauce of green leaves or vegetables. In this mainly patrilineal social order, women grind the maize in large mortars and pestles in the household or take it to nearby mills (Sheldon 2002; Bertelsen 2014a). The maize meal ( $u f u$ ) is central not only as a staple food but also richly important for cosmological and symbolic dynamics, often related to death and the regeneration of life, notions of fertility and instrumental in dealing with the problem of sorcery. ${ }^{1}$

For the purpose of procuring this vital maize meal, a household will normally work two varieties of plots of land differentiated by how moist the soil is and how close to running water, lush groves or streams these are located. The most humid or wet type of plot, the matoro (or baixa, from Portuguese "low") is used to grow waterintensive crops such as banana (nzerapera), sugarcane (musare), tomatoes (matemate), yams (madumbe), lettuce and beans (nhimo, nhemba, dodsi). 2 The dry-field plot, the machamba, will normally constitute the brunt of any household's pieces of land and is in the main used to grow maize and sorghum, while usually interspersed between maize stalks will be cucumbers, pumpkins, groundnuts or various strands of bean. Adding to the two types of land above, the

\footnotetext{
1 This is also the case for other Southern African contexts, as for instance Maia Green (1997) elaborates in the Tanzanian rural context of anti-witchcraft practices or as Niehaus (2005) has analyzed for rural South Africa where zombies were experienced to steal maize meal.

2 Except when otherwise noted all italicized terms here are given in chiTeve, the predominant language in Chimoio, Gondola and its rural and peri-urban hinterlands.
} 
area around the house will typically also be used as a garden where sweet potato and cucumbers are important crops.

All households also have a number of fruit trees providing important variation to the sadza-based diet and mango, lemon, tangerine, avocado and papaya trees are scattered across Honde's undulating hills. Ownership structures of these are complex, subject to shifting formations of tenure and the trees index symbolic and mnemonic features of the larger social and cosmological order. Besides what is grown, birds as well as mice, rats, water rats and other smaller mammals are hunted with slingshots or traps while larger animals are scarce. Whatever animals are consumed is strictly regulated by mitupo -a totemic clan membership indicating tabooed animal meats and parts (see also Huhn 2016). Sometimes to accompany the sadza small, dried fish of three to four centimeters in length and bought at local markets are prepared with salt and some oil, or the freshwater musopo, a large, oily catfish-like fish caught in rivers or reservoirs around Chimoio, is cooked.

This cursory introduction to rural foodstuffs may convey an impression that Honde and similarly rural Mozambican communities are oriented purely toward consuming their own produce but this, of course, is not entirely the case: Integral to local and regional economies and systems of trade for many centuries (Bhila 1982), the peasants' selling of agricultural produce in urban and peri-urban parts of town (bairros) is conditioned by historical patterns as well as shaped by current situations of dire poverty and structural violence. Importantly, however, such sale and trade is also circumscribed by notions of sorcery (uroi), as well as rumors of illicit and predatory forms of accumulation. As in the African continent more broadly, such rumors particularly affect how foodstuffs and cooking in households are conceived and thereby directly relate to the female domain of nurture which, in turn, is fundamental to sociality more generally (Berger 1995; Moore et al. 1999; Bertelsen 2011, 2014a). Crucially, such highly gendered traits emphasizing nurture extend beyond individual households and into wider society: Women will visit each other to provide foodstuffs, borrow utensils for cooking, make and distribute pottery for making foodstuffs, lend maize meal or exchange seeds and seedlings. And perhaps most important of all: When harvest is undertaken, women gather at each other's households to help peel the cobs or prepare various forms of food and (alcoholic and nonalcoholic) drinks from maize.

Counteracting a central aspect of sorcery (uroi) in this area-that which sees it as materializing as poison in foodstuffs (see also Bertelsen 2011) - the very act of preparation of sadza is a form of gendered social intimacy, effectively expansively propelling the household outward transgressing its erstwhile boundaries. Such a centripetal orientation premised upon and valorizing social proximity is also 
practiced directly through how women (and sometimes men) upon departure will provide the guest with a number of foodstuffs (hens, bananas, maize-or foodstuff to be, like seeds and seedlings) to take home with him or her. Again, this directs the household's nurturing capacity outward, as is also seen on the paths which cut through bush, agricultural plot or urban bairros as veins of an expansive sociality: Often en route to markets with foodstuffs or homeward bound with goods, women embody and energize the important circuits that these paths represent and at the same time exchange pieces of news and stop to visit familiars and friends. A third example of this valorization and practicing of social relationality and generativity is found in the domain of collective labor: Also here women generally oversee and organize labor power so that it conforms to proper arrangements, such as in the institution of djangano which mobilizes neighbors and kin $(d z i n d z a)$ for specific labor-intensive tasks, for instance weeding a matoro or machamba. Increasingly as the task nears completion, the participants are given traditional maize or sorghum beer (duro) underlining a reciprocal ethos. ${ }^{3}$

In such a context, to clandestinely elicit the labor power from his or her fellows, as is the work of the sorcerer (muroi), effectively negates or inverses the reciprocal, collective mechanisms of djangano: By extracting labor power, foodstuffs or the very flesh of people, the muroi illicitly privatizes resources for consumption-epitomizing the nature of antisociality. In its most concrete sense, this involves sorcerously drugging someone to nocturnally or invisibly perform labor on your machamba or matoro, so-called kurima no zwiphoko (see also Bertelsen 2016: 173-174).

Notwithstanding the challenge from the muroi-to which we will turn below-generally these dimensions of women's practices imply that it is highly problematic to approach the household as a bounded productive, socioeconomic entity. The dimensions also ethnographically indicate how women are charged with a generative potential of the community's sociality and relationality as such. In this sense, women's practices are directly socially constitutive and, from the perspective of food and production, women may be seen to nurture society and vice versa (see also Carsten 2004). In other words, women occupy key positions not only as nurturers in a limited sense but as key practitioners in the formation of local community and social and reciprocal relations more generally.

This article will explore the particular form of generativity cursorily introduced above through presenting and analyzing two

\footnotetext{
3 See also Chapman (2010: 89-99) who provides a highly valuable and minute analysis of the gendered dimensions of labor in Gondola. Further, similar dynamics of djangano is well-documented from rural Zimbabwe where it is often spelt jangano (see e.g., Bourdillon 1987: 74).
} 
ethnographic cases of so-called zwidoma-sorcerous creatures that relate intimately to women's practices and roles but which are oriented toward harnessing and increasing monetary wealth. As will be shown toward the end of the article in a comprehensive section drawing on these empirical cases, what may be understood by value in this context will be analyzed in relation to what will be shown to be the zwidoma's double-edged nature; it both generates wealth and its potential while, simultaneously, also subverts various registers of value. In undertaking such an analysis, notions of value creation or generation in capitalist circumstances will be juxtaposed with processes of generativity and subversion in the particular Mozambican context.

\section{Two Cases of the Zwidoma Triptych}

As already hinted, women's generative social capacities are circumscribed by cultural imaginaries of the muroi in its female guise. Although I have found no predominance of women believed to be or attacked as sorcerers statistically outnumbering men, certain characteristics nevertheless seem to indicate female generativity as prominent for sorcery. I will limit myself here to analyzing one fundamental materialization-or, rather, an embodiment-of such problematic generativity: The zwidoma (plural; tchidoma sing.).

Zwidoma are in almost all instances related exclusively to women and, importantly, also to problematizing the accumulation of pecuniary wealth. This becomes evident in this excerpt from an interview made with a prominent traditional healer (n'anga) in Chimoio. ${ }^{4}$ The interview was carried out in a bar in 2007 and starts by the healer, "J", replying to my question about the nature of zwidoma:

$\mathrm{J}$ : Zwidoma are a tiny couple which may be used in maneuvers to get rich. They are people that are around 40 centimeters tall. They may be used to take money out of the houses of people. One may use them to get rich in five years. After five years, you may die or become very ill but rich. They are people of sorcery [uroi], right?

B: Yes ...

$\mathrm{J}$ : Therefore, they need to be treated well as it is they who do all the work. They do not eat anything but meat. The only thing they cannot eat, are vegetables. They need meat only! The mother of the family who does this maneuver [i.e., controls and sustains the zwidoma] needs to cook a large pot of meat each day because they eat a lot.

\footnotetext{
4 The notion of anapatch, a chiSena term describing a phenomenon near identical to zwidoma, is also commonly used in Chimoio, Gondola and Honde. Its use there illustrates the way in which terms as well as different understandings of relations and processes related to uroi and, more broadly, cosmological horizons migrate and are constantly re-localized and appropriated. This point is also underscored by its appearance in the Shona-speaking areas in Zimbabwe across the border.
} 
B: Are there many who have these in Chimoio?

J: Chi! Plenty of people have this.

B: And when you die after five years, what happens to the zwidoma?

$\mathrm{J}$ : They disappear. Another thing with this richness. A man called [...] here became very ill when he became rich. I told him "let's go to the hospital" but he never wanted to go. He refused, really. And each time after he had finished being ill, a new car or minibus [for his transport company] came to him. Each time!

B: So, you need to become ill to become rich?

J: Yes, it demands a lot [i.e. costs and demands a lot, custa muito].

$\mathrm{B}$ : But these zwidoma, are they dangerous?

J: Yes, they might be. They may even kill your own children. It is dangerous to play with them. There was this man here who did that. He was in the traffic police in Chimoio and called [...]. You have heard, haven't you? [Calls out to the woman running the bar]

Lady: Yes, I have. [...] became very rich.

J: Yes, yes. Only when you do this maneuver, you cannot be unfaithful [literally "go outside," andar fora]. It is dangerous.

B: And he did this? Was unfaithful?

$\mathrm{J}$ : Yes! He was unfaithful and died. But his mother still has all the money.

B: So, the money does not disappear when you die?

J: No. Your family may be left with a lot of money.

In January 2016 I had the opportunity to follow the ebbs and flows of goods and people at a large, informal urban market in Gondola. Having discussed profits, trade, customers and strategies with a small group of middle-aged male stall owners ( $\mathrm{X}, \mathrm{Y}$ and $\mathrm{Z}$ ), the conversation one day turned toward zwidoma:

$\mathrm{X}$ : [Pointing to a run-down house a few hundred meters away] Do you see that house over there - there in the distance? The one that looks derelict?

B: Yes ...

$\mathrm{X}$ : That there is where a woman here tried this trick of the zwidoma.

[Y and $\mathrm{Z}$ affirming strongly and vocally this to be the case.]

$\mathrm{X}$ : What happened was this: There was a woman in the house that wanted to have these zwidoma, so she organized to get some from a n'anga [traditional healer]. These zwidoma worked well for her-food came into the house, money came into the house. Zwidoma can travel long distances; at night they can even take your car and come back with things. But they need a lot of food; always food with a lot of meat. And the woman and the man [that comprise the zwidoma couple] walk around naked and shit and piss everywhere in the room that they have. So, it is a lot of work for women and they become exhausted! [Pointing at the house] This one [woman] became mad and ran away. 
B: Oh ... And what happened then?

Y: The husband was alone in the house with the children and the zwidoma. The zwidoma are always very nervous [zwidoma são sempre nervosos, maningue]. And there are strong rules for the zwidoma, they need a woman-otherwise the zwidoma become mad [chateados]. So, they started abusing the children [sexually] when then the woman was gone. The man could not handle them-it was not his zwidoma and the woman had run away! So, he took the children and ran away. Now, no one goes near the house ...

B: So, the house is dangerous still?

Z: Look, the zwidoma are still there. I see them sometimes when I pass in the afternoon. Then they walk around in the garden, naked, whistling. It is around 18.00 [dusk].

B: So, this house - no one wants to live there?

X: You cannot! No one will. There are other houses here that have zwidoma [pointing in two other directions and elaborating on their exact location, supported by the two others]. And there are many we do not know about. Zwidoma? Ah, many [maningue]!

The characteristics of the zwidoma in these ethnographic excerpts seem to resemble the sacrificial logic well-described for sorcery in Mozambique (West 2005; Bertelsen 2009b, 2016). For instance, both cases show how zwidoma exhibit the features of zombification in which one's bodily energy is slowly sucked dry through engagement with sorcery, although here such engagement is complicit. The presence of zwidoma also instantiates what we may term an antisocial centripetality, with its epicenter being a specter of violence in the domain of the intimate: One's children could potentially die or, as was clear in the 2016 case, be socially, physically and mentally destroyed through (sexual) abuse. Such antisocial violence attacks the centrifugal form of sociality and relationality inherent in the female domain of the household. Clearly, violence in this format and directed towards such intimate domains, comprises a sacrifice of either self or others reflecting the almost perennially double-edged character of sorcery (see, for instance, Kapferer 2002). As in almost all accounts of what we define as sorcery, its transgressive character is precisely what imbues it with power. Here, this is indicated by the grotesque paradox of the zwidoma being corporally miniscule while simultaneously devouring an obscenely large diet of almost pure meat. Both the carnivorous consumption and the miniscule shape stand out in this excruciatingly poor area where most inhabitants taste meat perhaps merely once month-barring birds, smaller mammals and dried fishas also alluded to above when elaborating a generally protein-poor 
diet (which also results in high rates of malnutrition and child mortality). ${ }^{5}$

An ethnographic analysis from nearby Manyikaland, Zimbabwe, on the zwidoma may here help elucidate, complement and contrast some of the features that have emerged in the two Mozambican cases. In her study, Jacobson-Widding interestingly points out direct relations between women, cooking and sorcery, labeling the zwidoma couple as crucial to the female sorcerer. The sorcerer is "recognized by her dripping or ulcerous nipples. She is constantly suckling small creatures, her familiars, who are called zwidoma. Typically, her activities are sexual in nature. She rides a white hyena at night" (Jacobson-Widding 1990: 57; italics in original). Further, the zwidoma are "dwarfish" and are thought to inhabit "the ground under a woman's cooking hut" (Jacobson-Widding 1999: 303). Jacobson-Widding's ethnographic characteristics complement mine in also allocating agency and control to childbearing women and in emphasizing the zwidoma's relations to cooking and food (i.e. cooking hut and meat lust), to extractive capacities (milk from "ulcerous nipples" and illness) and, finally, to a sexualized orientation. Also here we see that the triangulation of the muroi and the zwidoma embody transgression, where the woman's engagement is conceived in sexual terms involving the figure of the hyena (which, counterintuitively, is white, a very rare color for this animal).

Jacobson-Widding's thorough ethnographic work from the Shonaspeaking context in Zimbabwe exemplifies common cosmological themes in rural Southern Africa, as also shown by P. Miller (1979: 263) as one of the few other published pieces mentioning the zwidoma. ${ }^{6}$ However, the centrality of gendered generativity should be evident in Jacobson-Widding's case and this also resonates with my interlocutors in Gondola, Honde and Chimoio: Time and again it was underlined that it is "the mothers" (as mães, in Portuguese), i.e. women who have reached or surpassed the childrearing age, that sustain and control the zwidoma. While, as in the first case, the zwidoma and woman constellation may, ultimately, benefit both men and women in the marketplace or in economic activities more broadly, women are nonetheless exclusively identified as the genitors for such illicit accruement of value, as their bodies sustain sorcerous creatures

5 See also Pfeiffer (1997), Kalofonos (2008) or Schuetze (2010: 404-409) for additional excellent analyses of food, nutrition, gender and household dynamics in the region.

${ }^{6}$ Reflecting a more generic approach to the wider Shona cosmological framework is Bucher's (1980: 111) short comment about what he also calls the zwidoma where these are, simply, various sorcerous animals appearing in households and being "a witch's familiars (zwidoma) whom she has sent there to hide her dangerous 'medicine' in and around the houses where it will cause harm to both man and beast." Bucher seems not to have grasped the miniature couple-woman constellation integral to the assemblage that is so prevalent in Manica and Sofala provinces in Mozambique and also across the Zimbabwean border in Manicaland Province. 
at a high cost-in monetary, corporal and social terms. Metaphorically, the reproductive and nurturing female capacity of women as central to household food production are expressed by female custodianship of the zwidoma.

The risky nature of such a nefarious, antisocial and subversive form of generativity emerges when the woman ceases to be part of the assemblage-when the triptych becomes a diptych: Fueled by their destructive orientation when not nurtured and placated, the zwidoma will then vengefully attack kin and family, as in the second case where the remaining husband and offspring were targeted. The antisocial and anti-generative expanse of the zwidoma laid bare is no longer contained by the parasitic and predatory, yet generative, relation to a woman: The zwidoma radiate destructively and centripetally, grotesquely inverting and mimicking the expansive centrifugal sociality of households. As such, their destruction also provides an empirical instance of how sorcery may be emplaced centrally within the household and how it remains an unequally distributed potential among its female members.

\section{Value and Subversion: The Zwidoma-Woman Triptych Analyzed}

At first glance, the zwidoma-woman triptych conforms to the wellrehearsed argument of commoditization effected by capitalism-a particular instance of how value may be addressed, we might sayleading to what John and Jean Comaroff famously term "occult economies." Providing an imaginative and rewarding framework to probe relations between sorcery, wealth and accumulation, they propose such a dynamic to have a global reach (Comaroff and Comaroff 2001: 19). Crucial to their argument are processes integral to capitalism itself-shifts, for instance, from production to consumption and from material to immaterial labor (Comaroff and Comaroff 1999) which have also been argued by others (Hardt and Negri 2000; Pignarre and Stengers 2011; Harvey 2014). Given the worldwide economic crisis and the emergence of increasingly elusive, non-transparent formations of capital and the reaping of its values by a class of seemingly unscrupulous capitalists (Piketty 2015), the term "occult economy" seems more apt than ever to describe these bleak circumstances. Moreover, the vision of occult economies encompassing worldwide productive, consumptive and exclusionary relations provides a powerful critique of the unfulfilled promises of ongoing neoliberal transformations of capitalism and the state (Kapferer and Bertelsen 2009; Sassen 2014). Such global dynamics also correspond with critical analyses of corrupt accumulation and the asymmetric patterns of Mozambique's economic growth (Cunguara and Hanlon 2012; Castel-Branco 2014; Mozambique News Reports and Clippings 
2016) which have fueled several large-scale, violent political protests (Bertelsen 2014b). However, the idea of "occult economies" and related approaches nevertheless may be seen to problematically subsume ethnographically situated and highly complex values external to the capitalist system within its analytical purview. In other words, it fails to provide an in-depth analysis of peri-capitalist zones that recognizes those aspects relating to domains encompassing social, cosmological, corporal and gendered aspects—such as, in this case, the value of generativity. ${ }^{7}$

One way in which to avoid such an impasse in the case of the zwidoma-woman triptych-to attempt to locate its value, so to speak - is to begin by situating its emergence and perpetuation as the outcome of specific historical trajectories of economy, gender and the social order. Such Mozambican trajectories cannot be understood without taking into account the severe impact violence has had on both urban and rural livelihoods and economies in the last decades: Embroiled first in a war of independence from the repressive Portuguese colonial rule (1964-1975) followed by a devastating civil war with international ramifications and local dynamics (1976-1992), ordinary Mozambicans have suffered from long-term destruction on a scale almost unimaginable (Nordstrom 1997; Lubkemann 2008). Manica Province and the rural areas around its capital Chimoio were no exception and severely affected by the civil war, many of its inhabitants therefore seeking refuge in urban areas. However, while generally living in squalid and marginal conditions during war, the situation nevertheless still afforded opportunities for some, especially women. Chingono (2015), for instance, contends that women seized economic opportunities provided by the onslaught of war through establishing themselves as, for example, traders. ${ }^{8}$ More broadly, this particular region of Mozambique is one where an argument about "gendered entrepreneurship" as an (after-)effect of the turmoil occasioned by war could be made. My own material, elaborated

${ }^{7}$ For three other empirically founded critiques of the notion of occult economies in Mozambique, see Bertelsen (2009b), Israel (2009) and Sumich (2010).

8 Whether market liberalization, commodification or deregulation is viewed as beneficial or detrimental to women as a group is often based on whether these processes are analyzed as emancipatory of structural constraints inherent in existing sociopolitical or economic orders, or whether the transformations they represent entail a further marginalization and/or loss of position(s). For three views based on Mozambican material, see Monteiro (2002) as arguing for further marginalization of Mozambican urban women, Sender et al. (2006) and Sheldon (2002) arguing for these processes having differentiated outcomes, while the before-mentioned Chingono, contrarily, argues for new opportunities afforded to Mozambican women by war and deregulation $(1996,2015)$. More recent material, for instance from Paulo et al. (2011), seems to indicate that as a general pattern especially urban femaleheaded households experience a sharper drop in poverty rates than non-femaleheaded ones. 
elsewhere (Bertelsen 2016), also points to similar processes entailing the reassertion of control by rural women in Honde over productive and reproductive forces. While there is no space to go into such processes here, it underlines the non-static dimensions of relations between nurturing, production and sociality-a fluidity essential to analyses of rural and peri-urban society in Mozambique.

And here we are, of course, at a larger point regarding categorization and, thereby, universalization: In this text, I have consistently used the term "woman" and "man" as rather static and fixed analytical categories. However, as the material on the zwidomawoman triptych has shown, the very category of mankind we usually call "woman" is rather unstable, open and forgeable-much as were Chingono's post-war women (Chingono 1996, 2015). In her brilliant and recently translated incisive text "Who Knows What a Woman Is," Annemarie Mol (2015: 73) adroitly deconstructs the category of "woman," writing:

...every unit to which you might ascribe a definition of woman or female may itself be subdivided into smaller units that each do something slightly different. There is no uniformly used category of woman or female within a century, a culture, a place, or even the institute that presents itself as the apogee of coherence: science.

Mol's trenchant and important critique might also be levied against how the category of "woman" (and "man") is used in this article. However, through showing the very exposure of "woman" in these circumstances as potentially being part of triptychs, of assemblages involving multiple, extensive and expandable bodies, I hope these cases will rather contribute to questioning an aspect Mol also is concerned with, namely this: Where does the body end and begin? Such fluidity of multiple points of connectivity and unstable and fleeting multicorporality, are, of course, traits integral to the very dynamic of the zwidoma-woman triptych itself. Here, the accruement of economic value seems to rest on a circulation of substances through bodies or substances being reworked by bodies-accentuated by the female body nurturing the creatures. This nebulous road to accruement of value is, further, predicated upon the appropriation of a subservient married couple-both serving and being nurtured by the market woman's corporal self.

As Geschiere (2013) has established in his overview of witchcraft in both Europe and Africa, its appearance is frequent within the domain of intimacy-the family, relationships between neighbors and other forms of social proximity. Geschiere's argument is generally also valid here as the very substance on which the zwidoma feed is a corporalization of intimacy, relationality and sociality-the female body. Nevertheless, the zwidoma comprise more than merely being an 
expression of the ambivalence of intimacy in relation to witchcraft as their existence embodies a skewing and transmogrification of also the idealized married couple-a miniature but with grossly exaggerated features. The exaggeration is, of course, a staple feature not only of cosmologies of sorcery but also of wider sociocultural understandings of consumption (including eating), production and predation. As with notions of the carnivalesque, the grotesque of a double figure-the zwidoma are after all a pair, a duality onto itself-constitutes a twin ultra-consumer of precious foods, gorging itself on meat, as well as devouring the very origins of generativity, a woman with childbearing capacity. ${ }^{9}$

In a sense one may therefore understand the double figure of the zwidoma and its relation to a woman as an intensified version of generativity-a triptych also of diabolical proportions, if one is biblically inclined. However, in more analytical terms there is also an element here of realization of potential for the accruement of value that needs to be understood-a realization that remains unconstrained or uncontained by the economic sphere alone, by manuals prescribing market liberalization, by common descriptions of African informal economies. In order not to merely tag such dynamics with terms such as "occult economy," one way to approach what I have termed "generativity" is through the Deleuzian (2006 [1977]) notions of "the actual" and "the virtual"-both aspects of what one normally describes as components of the real: As I have described more fully elsewhere (Bertelsen 2016), the domain of what can be termed the traditional as an integral part of social ontology encompasses a vast range of outlooks, repertoires and logics as well as institutions and other physical set-ups in time-space. While often relegated to the role as modernity's Other or being presented as a result of colonial processes of ordering (e.g. Hobsbawm and Ranger 1992 [1983]), this is instead approached as a realm that produces virtual realities. Crucially, virtual here does not signify "virtual realities" or simulacra of the empirical in the sense of being individual personal fantasies or other insular forms of the imagination. Rather, "virtual" is a vastly broader concept launched to helpfully encompass a non-actualized reality where "actual" describes the tangible "state of affairs"-for example observable social processes (Deleuze and Guattari 1994

\footnotetext{
9 Inspired by Bakhtinian readings of Rabelais, Mbembe (1992: 4) has famously argued for the domains of the grotesque and the obscene as inroads into understanding the nature of power in postcolonies: “...as a means of resistance to the dominant culture, and as a refuge from it, obscenity and the grotesque are parodies that undermine officialdom by showing how arbitrary and vulnerable is its officialese and by turning it all into an object of ridicule." While I will not go into it in detail here, Mbembe's argument about the postcolony might also be extended to Mozambican sociopolitical order where figures such as the zwidoma may be seen to interfere with predominant hierarchies of gender, power and the ideologies of the market and its logics.
} 
[1991]: 155). Contrary to this realm of the tangibly empirical, Deleuze posits and accords a reality to the virtual and is adamant in his critique of philosophers (as Leibniz) who frequently conflate the virtual with the possible in a process where " $[\mathrm{t}]$ he possible is opposed to the real; the process undergone by the possible is therefore a realisation. By contrast, the virtual is not opposed to the real; it possesses a full reality by itself" (Deleuze 2004 [1968]: 263).

Deleuze's position is radical in both an ontological and epistemological sense by according a reality to the virtual which normally is represented as a bleak reflection of a universal and monoempirical starting point-the real. Crucial for us here is that this composite reality of actual and virtual captures the bringing into the realm of the socioeconomic order an element normally seen to lie outside it. In a very concrete sense, the virtual of the domain of women's generativity is actualized to the effect of an accruement of value in defiance of conventional understandings of value and valuation in relation to commodities and the working of the market.

There are, however, additionally significant dimensions here to ponder: For one, the zwidoma-woman assemblage embodies, literally speaking, the actualization of productive flows, food and the female body that, crucially, also challenge gendered, hierarchical social orders. Taking this into consideration, it becomes reductive to label it as solely oriented toward the accruement of value in economic terms-also as the assemblage's potentiality lies precisely in elements and structures that are frequently antagonist to or outside market economies and social systems alike. Clearly, and deriving from the transgressions entailed by enlisting the zwidoma couple, such processes of valorization are precisely actualized through upsetting the domains of the social and the economic. In turn this entails that the concern with, if we may use terms derived from economy, accumulation by illicit and sorcerous means to increase profits-as the cases above underlinetranscends the supposedly present moment of "millennial capitalism" or a globalized "occult economy." For one, this is so as the zwidomawoman triptych is fueled by and amplifies visions of gendered fertility, notions of an extensive sociality and, not least, the sociocultural value placed on the production of maize flour and cooking. However, such dimensions are, again, irreducible to a formalist approach to capitalism as the zwidoma-woman triptych transcends the locale of the urban marketplace-and the present historical moment-by being a long-standing sorcerous configuration reflecting rural and peri-urban concerns with generativity, sociality and fertility. In sum, therefore, the auto-fertilization inherent in the zwidoma feeding off women's bodies 
both recognizes and subversively thwarts this valorization of the intimate and key relations between food and women's bodies. ${ }^{10}$

This concern with generativity and multiple African worlds and modalities of production, corporality and food is not unique to Mozambique, of course. Parker Shipton (2014: S57) has pointed this out in a beautifully written account of long-term Luo relations of animal sacrifice and reproduction, noting that "[s]ome of these forms of value-indeed most of them-defy calculation, like a life, breath, or heart pulse offered up-or the life expected to be given safeguarded in return." Following Shipton's argument about recognizing locally produced and contextually sensitive forms of value, if we are to approach its accruement in such rural and peri-urban African contexts (and elsewhere) we need to acknowledge the longue durée character of such concerns which in Mozambique encompasses at least the era from late colonialism onward.

More broadly, the two Mozambican cases and the supplementary Zimbabwean material comprise, I argue, one ethnographic answer to the question regarding how societies deal with multiple value systems in a way that does not lead to the total domination of one system by another (see also Otto and Willerslev 2013). Crucially, the zwidomawoman triptych may not only be approached as an actualization of the virtual component of reality — as I argued above-but also highlights a feature of human dynamics and transformation more profoundly: Creativity. As Castoriadis has so eloquently established, the human being is in the last instance oriented toward his or her own human selfreinvention (Castoriadis 2007 [1999]: 16; see also Kirtsoglou 2010: 3):

Anthrōpos posits himself as anthrōpos; the essence of anthrōpos is self-creation. This phrase is to be understood in two senses: anthroppos creates his essence, and this essence is in itself creation and self-creation. Anthrōpos creates himself as a creator...

Famously coining such a pan-human creative capacity as vis formandi, Castoriadis proposed the notion of social imaginary (Castoriadis 1987 [1975]) as capturing the unceasing oscillation between chaos/flux (instituting social imaginary) and stasis/stability (instituted social imaginary)—the latter being an ossified structure perpetually challenged by, precisely, vis formandi (for a related argument, see also Wagner 1981 [1975]). Castoriadis's approach may be seen to theoretically reflect precisely the value of generativity not only in its positive and constitutive sense-but also in its capacities for inversion,

10 The money gained in the market by women is, in my research, often kept by them rather than handed over to the men in the household. In this way my material contrasts a point made by Signe Arnfred (2011: 241) for Northern Mozambique, arguing that there "[i]n general, women control the food and men control the money resulting from cash crops, even where women participate in the actual production.” 
subversion and mutation. By foregrounding human-centered generativity, it thereby presents us with a helpful expansion of a Deleuzian optic of virtuality and actuality that may be seen to infuse human beings, rather than to be generated in full by these, as Castoriadis would argue.

Such a vision of a human being as herself the creator of a total world with the capacity also to transcend the confines of social orders resonates with how a reservoir of potentialities are actualized in line with regular market logics of value and its production-and sometimes subversive of the same. In this case the zwidoma-woman assemblage historically emerges and reemerges in the context of the marketplace and elsewhere to encompass, destabilize and subversively question the accruement of pecuniary value and accumulation.

\section{Value and Valorization, Creativity and Subversion}

Above some attempts have been made at exploring a particular assemblage constituted by a woman and a miniscule couple (zwidoma) engaged in a nefarious form of generating wealth. As I have established, this sorcerous triptych is well-known within urban, periurban and rural central Mozambican environments for generating money in the marketplace. If approached from a perspective of exchange-value, one might see such an assemblage as merely reflecting a desire for the accruement of monetary value. However, by focusing specifically on the emergence, dynamics and flows of substancescorporal, spiritual, alimentary and material - the article has sought to reframe understandings of wealth and accumulation as represented fully by a capital-centric view. Although helpful in terms of decentering capital as a monosemic and universal entity indexing monetary worth, it is here suggested that a singular notion of capitalism as understood within economic parameters has become a template that, paradoxically, universalizes and expands a narrow understanding of production, (re-)distribution and consumption. This particular analytical flattening does not, thereby, take into consideration the gendered dynamics inherent in the production and generativity characterizing economic life, social orders and cosmological horizons. Drawing on the empirical cases, it seems clear that any understanding of the nature of markets and its produce-including processes of alternative valuations-needs to recognize potential and possible realities that comprise, effectively, a subversion of the (hegemonic) fiction of market logics and values-a subversion also through existing outside its domain and tentative reach, in its peripheries.

But how are we, then, to understand the notion of "value"- - a term with a protracted history in anthropology (see, e.g., Peacock and McFadden 2015 [2001] for an overview)? As D. Miller (2008) recognizes, there is no shortage of theories of value in anthropology- 
including conceiving of value in terms of encompassment, hierarchical systems and supremacy in Dumont's sense (Dumont 1970 [1966]; see also Rio and Smedal 2008). Further, anthropological approaches to value have variously encompassed emphasizing a cultural schema approach, deployed a sociological reading or conceived it in an historical-materialist fashion as reflective of economic configurations - as related to exchange, as related to worldviews or as a synthesis between the two, as summarized by Otto and Willerslev (2013: 3). Reflecting such diverse readings, it seems safe to assume that it has become more commonplace to apply a more dynamic understanding of the notion-within anthropology (Ortiz 2013, 2014) and without (Doganova and Muniesa 2015). Exemplifying such a comprehensive approach melding perspectives from various societal, economic and political domains, Narotzky and Besnier's (2014: S4) recent definition is helpful, seeing value as "...a terrain where people negotiate the boundaries defining worth, operating at the intersections of institutional top-down normative frameworks and collective bottomup meanings and obligations." Their approach pries open the notion of value to see it as integral both to contexts of conjunctures and plural regimes, as well as forms of conflict and ambivalence. Moreover, they see "economy" not only in terms of "...making a living without privileging a particular domain of activity (exchange), a particular intentionality of action (gain), or a particular valuation process (calculation)" (2014: S6) but also, in a rather self-proclaimed neosubstantivist vein, as oriented toward “...sustaining life across generations" (ibid.; see also Gudeman 2012). Emphasizing cyclicity/life and duration/temporality, Narotzky and Besnier's (2014: S14) approach is rewarding as it fleshes out an anthropological vision of value in relation to the economy based on the "...struggles and stabilization around the worth of people and how to make life worth living."

However, Narotzky and Besnier's take nevertheless seems to privilege a capital-centric or econo-centric basis by introducing notions of hierarchical relations of asymmetry-a bottom comprised of social organizations, cultural orders and everyday lives (the domain of the humans) versus a top layer of generalized laws, political institutions and normativity. Contrarily, as for instance Ortiz (2013, 2014) has shown, the notion of monetary value-even in the context of the financial industry-cannot be seen as autonomous or as having an a priori existence as it is always already embedded in plural regimes of human (non-monetary) values (Ortiz 2013: 66). In line with Ortiz, I therefore find that Narotzky and Besnier's emphasis, although dynamic and abrasive, on negotiation, transactionalism or sociality needs to be complemented as "value" needs to be approached beyond notions of capitalist-produced relations of asymmetry and hierarchy. 
In an interesting work, Graeber (2001) seems to argue for such a dynamic and composite notion of the term. For him (2001: xii), value is best approached "as the way in which actions become meaningful to the actor by being incorporated in some larger, social totality-even if in many cases the totality in question exists primarily in the actor's imagination." If employing such a reading of value to the zwidomawoman triptych, the woman must be seen as inherently engaged in "meaningful action" within an order not fully regulated by market logics of valorization but rather expressing a reality of the generative potential of the social-also of the subversive kind undercutting dominant economic dynamics as these are commonly understood. After all, as Graeber (2001: 259) points out in a manner resembling both Deleuze and Castoriadis: "However elusive, creative potential is everything."

Nevertheless, Graeber's actor-centered creativity needs, I believe, to be tempered by the inherently collective character of value-a feature usefully pointed out generally by Helgesson and Muniesa (2013). Uzendoski's (2004) eloquent analysis of beer, meat and hunting among the Napo Runa in Ecuador may provide a case in point, albeit from a clearly totalizing anthropological point of view: Outlining how various forms of substances from animals and plants are transformed through labor and gendered complementarity, Uzendoski identifies sites for production of value where this is "...a perspective deriving from the totality of reproduction, the configurations by which society reproduces itself through the co-ordination of parts and wholes" (2004: 884). Uzendoski's analysis also seems to correspond to the two crucial components from Narotzky and Besnier, namely duration/temporality and life/cyclicity.

Informed by these latter perspectives from Narotzky and Besnier (2014), Graeber (2001) and Uzendoski (2004), values-and the value of generativity in this case-may be assumed neither to be stable and passive, as slots or categories in a cultural schema, nor as merely being the residue of sociological circumstances. Nor must they be understood representationally, as various metaphors of the market and transactions or as terrains upon which worth is ascertained and unidimensional and monosemic hierarchical indexes are systematized and generated. Away from such stale culturalism or tit for tat econocentric transactionalism we need to understand value as continuously created (and not uniformly replicated/repeated): A potential that reverberates and mutates to encompass and forge various domains, shape practices and give trajectories to cosmological horizons of thought and understanding reflecting, again, duration, temporality, life and cyclicity. This means that when I propose the term "alternative valuations" here, it is an attempt to move away from, especially, such econo-centric notions of values that too often impinge on readings of ethnographic material-despite the fact, as Ortiz (2014: 39) and others 
have asserted, that dominant financial concepts clearly entail meanings transcending the technical to encompass also, for instance, theological, political and moral dimensions.

A comparative case to bring out more clearly what I mean by alternative valuations is provided by Anna Tsing's (2015) recent and important work analyzing matsutake mushrooms and the worlds these and various other species co-create at what she identifies as the edges of capitalism. Tsing argues that market value thinking may be thought to have been spawned from the notion of the plantation; a controlled capitalist world of goods and labor and from whence was born the utilitarianist idea of scalability and market (Tsing 2015: 40). Tsing, therefore, professes that it is in the peri-capitalist zones-empirical domains not under the total command of a market economy-that we can both seek to anthropologically understand the world, asses its worth(s) and question capitalism (and, I will add, its hegemonic systems of valorization): "Pericapitalist economic forms can be sites for rethinking the unquestioned authority of capitalism in our lives" (Tsing 2015: 65).

Inspired by Tsing's approach to peri-capitalism, I will suggest that the zwidoma-woman triptych may precisely emerge in such a pericapitalist zone in Mozambique. Here, the dimensions of market transactions and consumerism is inextricably entangled with a value of generativity that affords multiple avenues to condensing material objects-of pecuniary and non-pecuniary value. Further, analyzing a peri-capitalist zone also strikes one as an ideal site for testing various notions of value more generally; both the notions of accruement of value internal to capitalist thought and alternative valuations, such as generativity, as a structuring yet dynamic and changing element of social formation, cosmological horizons and everyday practices. Put differently, in these peri-capitalist zones the prevalence of the zwidoma-woman triptych exemplifies particularly strongly how human generativity is in no sense wholly contained, shaped and codified by long-term, multifarious capitalist impulses (see also D. Miller 2008).

\section{A Final Note on Capitalist and Non-Capitalist Triptychs-and Alternative Valuations}

Reading the above analysis, one might have received the impression that capitalist forms of creating and generating value are non-complex. This is, of course, not the case: As mentioned above, Ortiz (2013) has pointed out that within financial markets, value is a thoroughly human creation and, further, that it is embedded within and generated by traders drawing on a range of political, theological, moral and social registers. Similarly, in their intriguing analysis of the emergence of business models as an increasingly important device for valuation and, thereby, also capitalization, Doganova and Muniesa (2015) show that 
value and valuation in such models stand in opposition to formal approaches to strategy and business decision-making processes. As opposed to flawed essentialist or functionalist critiques of business models, Doganova and Muniesa approach business models as multifarious assemblages that, crucially, rely on various modalities of performance, namely in the sense of an act or a narrative that convinces: in the sense of its scalability and projection toward the future; and lastly, in the sense of their reproducibility (2015: 111f). Crucial to these traits of the business model is therefore its plasticity and the multiple ways in which it, through performance, enrolls those within its reach to generate value through (expectations of) future capitalization. Again, not reflective of a technical or resource-oriented approach to value and growth, these dimensions to business modeling resemble, in some ways, the generativity of the zwidoma-woman triptych. In the business models in Doganova and Muniesa (2015) one may also argue for a triangulation (or triptychization) as central to value creation: Here, the business models facilitate highly beneficial configurations of investors, assets and entrepreneurs that work generatively and, indeed, Doganova and Muniesa's work demonstrates how such assemblages under the aegis of new business models generate a renewal of markets, exemplified through the businesses of Google and Genentech. Moreover, they also show clearly how business models as capitalization devices revolve around "asset-becoming" and futurity more generally.

In order to be brought out more fully, the correlations between the triptychs of the zvidoma-woman and the investor-asset-entrepreneur only hinted at here would require a comprehensive and comparative analysis that transcends the scope of this article. However, most crucially, one may ascertain that both are future-oriented and do not necessarily reflect technical and formal approaches to monetary or other conventional forms of resources. Moreover, both are plastic and pliable-in the Mozambican case the model of the zwidoma-woman travel both in space and time and from the rural to the urban, while for the business models this "mutatability" is inherent in its very configuration. Also, the logic of enrollment is clear-in the Mozambican case seen by how the power of the triptych dominated a range of discussions over accumulation and market business; and in the business model case the success of the businesses demonstrates its potential to enroll.

However, there are limits to comparing the two configurations of triptychs and one, which I would like to emphasize, is the implicit approach to value as inherently and universally generative in a positive sense evident in the business model triptych-an approach both Ortiz $(2013,2014)$ and Doganova and Muniesa $(2015)$ seem to subscribe to more generally. While this article seeks to move away from such a view, it should be noted, however, that I do not support an argument 
in the vein of a local population heroically upholding a singular, culturally determined, historically stable and alternative value in the face of the flattening pecuniary beams of global capitalism. Such arguments would be absurd in a region that has been exposed for a number of centuries to various forms of capitalist ventures from slavery, trade with Arabs and gold mining to plantations, concession companies deploying forced labor and markets as sites of exchange (Bhila 1982; Rennie 1984; Allina 2012). Rather, the zwidoma-woman triptych may be seen to index ongoing reshapings in a peri-capitalist zone revolving around the value of generativity that despite centuries of capitalist ventures, is still not yet subsumed by the inflexible market logic of pecuniary valorization nor is it purely positively generative.

More generally, Tsing's matsutake mushrooms and the zwidomawoman triptych instead exemplify two instances of peri-capitalist zones that may be much more prevalent than hitherto thought, at least if, wrongly, taking the total command of a capitalist system of values as a point of departure. Put differently, alternative systems of valorization spring forth, mutate and become integral to sociopolitical orders and cosmological infrastructures and impede practices, testifying to the fact that woman (and man) is not yet always already a Homo Economicus. Emphasizing creativity, generativity and subversion in peri-capitalist zones opens up, then, to seeing "value" in two complementary ways: First, as meaning pecuniary value, goods, commodities and material structures that are already recognized as internal to a capitalist system (money) or as potentially convertible within it; second, and this is what has concerned me here, as an index of valorization irreducible to capitalism where the eventual economic outcome is predicated upon virtual potentialities that are irreducible to market logics. Specifically, while I have approached the value of generativity akin, in a sense, to Uzendoski-namely as a life-affirming and regenerative orientation toward sustaining and reproducing (social) life and the cosmological order and its specific gendered dimensions-I have emphasized value as necessarily open-ended, fluid and as containing within it possibilities for both its subversion and its intensification. The woman-zwidoma triptych has here been seen as such an instance emerging from the value of generativity but one that is grotesquely intensified, expanded and revolving toward the inverse - caving in on itself.

The latter and open-ended meaning to value is also informed by the pitfalls of anthropological and other disciplines' metaphorization and substitution of situated understandings-as also powerfully argued by Rane Willerslev in his call for a guerrilla anthropology that destabilizes other disciplinary approaches to value (see Otto and Willerslev 2013). A similar point to Willerslev's, and one empirically founded, is made by Bonelli (2014) in his analysis of hemic feasting and the consumption and exchange of blood among Pehuenche where he 
shows that it is analytically highly problematic to reduce such empirical complexes to metaphors of relationality or material symbolism. Drawing on Lévi-Strauss (1955), Bonelli (2014: 108) writes that such an analytical move would in “...Lévi-Strauss' terms [entail] a destruction of the object of our attachment and its replacement with another that might be homonymous but pragmatically behaves quite differently.”

I concur with Bonelli's and Willerslev's general critique and for this reason also found it problematic to endorse the applicability of a notion of the "occult" in the Comaroffian vein as it relegates to the shadows, to the margins, to the domain of effects, to the flip side of the coin of capital, that which is a key engine of social formation: the domain of the virtual and its potential to actualize novel forms of accumulation (also capitalist but not exclusively so). This article has been an attempt to flesh out alternative ways to conceive of value's multiplicity other than rendering instances such as the zwidoma to a functional category of "the occult."

The triptych of the zwidoma couple and the woman congeal key aspects of the valorization and problematic commodification of certain substances that move between agricultural fields and the market or household, almost invariably mediated through the female body. Although indexing a universal collective and relational impulse, rather than instantiating a case of "intersubjective participation" (Sahlins 2013), the predatory and sorcerous flipside to the value of generativity -drawing on potential domains of reality and limitless human creativity only tempered by broader cosmological horizons-makes the imagery of the triptych apt. For the triptych provides the possibility of shifting between one, two or three persons-revealing, concealing and embodying the space of a gendered economy of substance, generation and accruement of value at the peri-capitalist fringe. The notion of "alternative valuations" does not only thereby include-in a dichotomous fashion-a singular set of other values in contradiction to a singular hegemonic or other consistent and finite system. Rather "alternative valuations" must also recognize the possibilities of values that contain within it the potential for its obverse-such as the zwidoma-woman triptych emerging from the value of generativity. 
Acknowledgements. This article is a heavily expanded, recontextualized version of a case study only mentioned in a very abbreviated form in Bertelsen 2016 (see especially pp. 215-217). In developing this article, I would like to thank Ton Otto, Bruce Kapferer and Steffen Dalsgaard for organizing a highly interesting workshop on value in Cairns in 2012 where this material was first presented. I also extend my gratitude to the two anonymous readers who engaged critically and fully with an earlier version of the text which, as a result, improved considerably. In addition, I would like to thank the editorial team of Valuation Studies and particularly Fabian Muniesa, Liliana Doganova and Lotta Björklund Larsen for consistently being professional and supportive. Last but not least: Maitabassa maningue to my long-term interlocutors in Chimoio, Honde and Gondola, Mozambique.

\section{References}

Allina, Eric. 2012. Slavery by Any Other Name: African Life under Company Rule in Colonial Mozambique. Charlottesville, VA: University of Virginia Press.

Arnfred, Signe. 2011. Sexuality and Gender Politics in Mozambique: Rethinking Gender in Africa. London: James Currey.

Berger, Iris. 1995. "Fertility as Power: Spirit Mediums, Priestesses and the Pre-Colonial State in Interlacustrine East Africa." In Revealing Prophets: Prophecy in Eastern African History, edited by David M. Anderson and Douglas H. Johnson, 65-82. London, Nairobi, Kampala, and Athens, GE: James Currey, E.A.E.P., Fountain Publishers, and Ohio University Press.

Bertelsen, Bjørn Enge. 2009a. "Multiple Sovereignties and Summary Justice in Mozambique: A Critique of Some Legal Anthropological Terms." Social Analysis 53(3): 123-147.

- 2009b. "Sorcery and Death Squads: Transformations of State, Sovereignty, and Violence in Postcolonial Mozambique." In Crisis of the State: War and Social Upheaval, edited by Bruce Kapferer and Bjørn E. Bertelsen, 210-240. New York, NY and Oxford: Berghahn Books.

- 2011. “'Entering the Red Sands': The Corporality of Punishment and Imprisonment in Chimoio, Mozambique." Journal of Southern African Studies 37(3): 611-626.

— 2014a. "Maize Mill Sorcery: Cosmologies of Substance, Production and Accumulation Engaged in Central Mozambique." In Framing Cosmologies: Anthropology and the Imagination of Worlds, edited by Allen Abramson and Martin Holbraad, 199-200. Manchester: Manchester University Press.

- 2014b. "Effervescence and Ephemerality: Popular Urban Uprisings in Mozambique." Ethnos: 1-28, DOI 10.1080/ 00141844.2014.929596.

- 2016. Violent Becomings: State Formation, Sociality, and Power in Mozambique. New York, NY: Berghahn Books. 
Bhila, Hoyni H. 1982. Trade and Politics in a Shona Kingdom: The Manyika and Their African and Portuguese Neighbours, 1575-1902. Harlow: Longman.

Bonelli, Cristóbal. 2014. "What Pehuenche Blood Does: Hemic Feasting, Intersubjective Participation, and Witchcraft in Southern Chile." HAU: Journal of Ethnographic Theory 4(1): 105-127.

Bourdillon, Michael. 1987. The Shona Peoples. Gweru, Zimbabwe: Mambo Press.

Bucher, Hubert. 1980. Spirits and Power: An Analysis of Shona Cosmology. Cape Town: Oxford University Press.

Carsten, Janet. 2004. After Kinship. Cambridge: Cambridge University Press.

Castel-Branco, Carlos Nuno. 2014. "Growth, Capital Accumulation and Economic Porosity in Mozambique: Social Losses, Private Gains.” Review of African Political Economy (41)S1: S26-S48, DOI http://dx.doi.org/ 10.1080/03056244.2014.976363.

Castoriadis, Cornelius. 1987 [1975]. The Imaginary Institution of Society. Cambridge: Polity Press.

—. 2007 [1999]. Figures of the Thinkable. Stanford, CA: Stanford University Press.

Chapman, Rachel R. 2010. Family Secrets: Risking Reproduction in Central Mozambique. Nashville, TN: Vanderbilt University Press.

Chingono, Mark. 1996. The State, Violence and Development: The Political Economy of War in Mozambique. Aldershot: Avebury.

- 2015. "Women, War and Peace in Mozambique: The Case of Manica Province.” African Journal on Conflict Resolution 15(1): 107-130.

Comaroff, Jean, and John L. Comaroff. 1999. "Occult Economies and the Violence of Abstraction: Notes from the South African Postcolony." American Ethnologist 26(2): 279-303.

- 2001. "Millennial Capitalism: First Thoughts on a Second Coming." In Millennial Capitalism and the Culture of Neoliberalism, edited by John Comaroff and Jean L. Comaroff, 1-56. Durham, NC and London: Duke University Press.

Cunguara, Benedito, and Joseph Hanlon. 2012. "Whose Wealth Is It Anyway? Mozambique's Outstanding Economic Growth with Worsening Rural Poverty." Development and Change 43(3): 623-647.

Deleuze, Gilles. 2004 [1968]. Difference and Repetition. London and New York,NY: Continuum.

—. 2006 [1977]. "The Actual and the Virtual.” In Dialogues II, edited by Gilles Deleuze and Claire Parnet, 112-115. London and New York, NY: Continuum.

Deleuze, Gilles, and Félix Guattari. 1994 [1991]. What Is Philosophy? London and New York, NY: Verso.

Doganova, Liliana, and Fabian Muniesa. 2015. "Capitalization Devices: Business Models and the Renewal of Markets." In Making Things Valuable, edited by Martin Kornberger, Lise Justesen, Anders Koed Madsen, and Jan Mouritsen, 109-125. Oxford: Oxford University Press. 
Dumont, Louis. 1970 [1966]. Homo Hierarchicus: An Essay on the Caste System. Chicago, IL: University of Chicago Press.

Geschiere, Peter. 2013. Witchcraft, Intimacy and Trust. Chicago, IL and London: Chicago University Press.

Graeber, David. 2001. Toward An Anthropological Theory of Value: The False Coin of Our Own Dreams. New York, NY and Houndmills: Palgrave.

Green, Maia. 1997. "Witchcraft Suppression Practices and Movements: Public Politics and the Logic of Purification." Comparative Studies in Society and History 39(2): 319-345.

Gudeman, Stephen. 2012. "Vital Energy: The Current of Relations." Social Analysis 56(1): 57-73.

Hardt, Michael, and Antonio Negri. 2000. Empire. Cambridge, MA and London: Harvard University Press.

Harvey, David. 2014. Seventeen Contradictions and the End of Capitalism. Oxford: Oxford University Press.

Helgesson, Claes-Fredrik, and Fabian Muniesa. 2013. "For What It's Worth: An Introduction to Valuation Studies." Valuation Studies 1(1): 1-10.

Hobsbawm, Eric, and Terence Ranger. 1992 [1983]. The Invention of Tradition. Cambridge: Cambridge University Press.

Huhn, Arianna. 2016. "What is Human? Anthropomorphic Anthropophagy in Northwest Mozambique." In Cooking Cultures: Convergent Histories of Food and Feeling, edited by Ishita Banarjee-Dube, 177-198. Cambridge: Cambridge University Press.

Israel, Paolo. 2009. "The War of Lions: Witch-Hunts, Occult Idioms and Post-Socialism in Northern Mozambique." Journal of Southern African Studies 35(1): 155-174.

Jacobson-Widding, Anita. 1990. "The Fertility of Incest." In The Creative Communion: African Folk Models of Fertility and the Regeneration of Life, edited by Anita Jacobson-Widding and Walter van Beek, 47-73. Uppsala Studies in Cultural Anthropology No. 15. Uppsala: Uppsala University.

- 1999. Chapungu: The Bird That Never Drops A Feather: Male and Female Identities in an African Society. Uppsala: Uppsala University.

Kalofonos, Ippolytos Andreas. 2008. "All I Eat Is ARVs": Living with HIVI AIDS at The Dawn of the Treatment Era in Central Mozambique. PhD thesis, University of California, San Francisco and Berkeley, CA.

Kapferer, Bruce. 2002. "Outside All Reason: Magic, Sorcery and Epistemology in Anthropology.” Social Analysis 46(3): 1-30.

Kapferer, Bruce, and Bjørn Enge Bertelsen (eds.) 2009. Crisis of the State: War and Social Upheaval. New York, NY and Oxford: Berghahn Books.

Kirtsoglou, Elisabeth. 2010. "Introduction: Rhetoric and the Workings of Power-the Social Contract in Crisis." Social Analysis 54(1): 1-14.

Lévi-Strauss, Claude. 1955. Tristes tropiques. New York, NY: Basic Books.

Lubkemann, Stephen. 2008. Culture in Chaos: An Anthropology of the Social Condition of War. Chicago, IL: University of Chicago Press. 
Mbembe, Achille. 1992. "Provisional Notes on the Postcolony." Africa 62(1): 3-37.

Miller, Danny. 2008. “The Uses of Value.” Geoforum 39: 1122-1132.

Miller, Penny. 1979. Myths and Legends of Southern Africa. Indianapolis, IN: T. V. Bulpin.

Mol, Annemarie. 2015. "Who Knows What a Woman is... On the Differences and the Relations between the Sciences." Medicine, Anthropology, Theory 2(1): 57-75.

Monteiro, Natalina. 2002. The Political Economy of Informal Markets: Restructuring Economies, Gender and Women's Lives in Maputo, Mozambique. PhD thesis, Northern Arizona University, Arizona, AZ.

Moore, Henrietta L., Todd Sanders, and Bwire Kaare (eds.) 1999. Those Who Play with Fire: Gender, Fertility and Transformation in East and Southern Africa. London and New York, NY: Continuum.

Mozambique News Reports and Clippings. 2016. "Survey Shows Inequality Doubled in Six Years.” Mozambique News Reports and Clippings, no. 306, 7 January 2016. http://www.open.ac.uk/technology/mozambique/ sites/www.open.ac.uk.technology.mozambique/files/files/Mozambique _306-4Jan2016_Big-Inequality-Increase_\%2B_other-reserarch\%20.pdf, accessed 31 August 2016.

Narotzky, Susana, and Niko Besnier. 2014. "Crisis, Value, and Hope: Rethinking the Economy." Current Anthropology 55(S9): S4-S16.

Niehaus, Isak. 2005. "Witches and Zombies of the South African Lowveld: Discourse, Accusations and Subjective Reality." Journal of the Royal Anthropological Institute 11(2): 191-210.

Nordstrom, Carolyn. 1997. A Different Kind of War Story. Philadelphia, PA: University of Pennsylvania Press.

Ortiz, Horacio. 2013. "Financial Value: Economic, Moral, Political, Global." HAU: Journal of Ethnographic Theory 3(1): 64-79.

- 2014. "The Limits of Financial Imagination: Free Investors, Efficient Markets, and Crisis." American Ethnologist 116(1): 38-50.

Otto, Ton, and Rane Willerslev. 2013. "Introduction. Value as Theory: Comparison, Cultural Critique, and Guerilla Ethnographic Theory." HAU: Journal of Ethnographic Theory 3(1): 1-20.

Paulo, Margarida, Carmeliza Rosário, and Inge Tvedten. 2011. 'Xiculungo' Revisited: Assessing the Implications of PARPA II in Maputo 2007-2010. Bergen: Chr. Michelsen Institute.

Peacock, James, and Hannah McFadden. 2015 [2001]. "Values, Anthropology of." In International Encyclopedia of the Social \& Behavioral Sciences. Vol. 2, edited by James D. Wright, Amsterdam: Elsevier. http://dx.doi.org/10.1016/B978-0-08-097086-8.12161-0.

Pfeiffer, James T. 1997. Desentendimento em Casa: Income, Intrahousehold Resource Allocation, Labor Migration, and Child Growth in Central Mozambique. PhD thesis, University of California, Berkeley, CA.

Pignarre, Philippe, and Isabelle Stengers. 2011. Capitalist Sorcery: Breaking the Spell. New York, NY and Houndmills: Palgrave Macmillan. 
Piketty, Thomas. 2015. "Capital, Inequality, and Power." HAU: Journal of Ethnographic Theory 5(1): 517-527.

Rennie, John K. 1984. "Ideology and State Formation: Political and Communal Ideologies among the South-Eastern Shona, 1500-1890.” In State formation in Eastern Africa, edited by Ahmed I. Salih, 162-194. Nairobi, London, and Ibadan: Heinemann.

Rio, Knut M., and Olaf H. Smedal. 2008. "Totalization and Detotalization: Alternatives to Hierarchy and Individualism." Anthropological Theory $8(3): 233-254$.

Sahlins, Marshall. 2013. What Kinship Is-and Is Not. Chicago, IL: University of Chicago Press.

Sassen, Saskia. 2014. Expulsions: Brutality and Complexity in the Global Economy. Cambridge, MA: Harvard University Press.

Schuetze, Christy K. 2010. "The World Is Upside Down." Women's Participation in Religious Movements in Mozambique. $\mathrm{PhD}$ thesis, University of Pennsylvania, Philadelphia, PA.

Sender, John, Carlos Oya, and Christopher Cramer. 2006. "Women Working for Wages: Putting Flesh on the Bones of a Rural Labour Market Survey in Mozambique." Journal of Southern African Studies 32(2): 313-333.

Sheldon, Kathleen E. 2002. Pounders of Grain: A History of Women, Work and Politics in Mozambique. Portsmouth, NH: Heinemann.

Shipton, Parker. 2014. "Trusting and Transcending." Current Anthropology 55(S9): S51-S61.

Sumich, Jason. 2010. "Does All That Is Solid Melt Into Air? Questioning 'Neo-Liberal' Occult Economies in Mozambique." Kronos (Bellville) 36(1): 157-173.

Tsing, Anna L. 2015. The Mushroom at the End of the World: On the Possibility of Life in Capitalist Ruins. Princeton, NJ: Princeton University Press.

Uzendoski, Michael. 2004. "Manioc Beer and Meat: Value, Reproduction and Cosmic Substance among the Napo Runa of the Ecuadorian Amazon." Journal of the Royal Anthropological Institute 10(4): 883-902.

Wagner, Roy. 1981 [1975]. The Invention of Culture. Chicago, IL: University of Chicago Press.

West, Harry George. 2005. Kupilikula: Governance and the Invisible Realm in Mozambique. Chicago, IL: University of Chicago Press.

Bjørn Enge Bertelsen is Associate Professor in the Department of Social Anthropology, University of Bergen, affiliated with the ERC Advanced Grant project "Egalitarianism: Forms, Processes, Comparisons." Bertelsen researches issues such as state formation, cosmology and violence in Mozambique and recent publications include Violent Becomings: State Formation, Sociality, and Power in Mozambique (Berghahn Books, 2016); Violent Reverberations: Global Modalities of Trauma (co-edited with Vigdis Broch-Due, Palgrave Macmillan, 2016); and Critical Anthropological Engagements in Human Alterity and Difference (co-edited with Synnøve Bendixsen, Palgrave Macmillan, 2016). 